\title{
Lymphadenopathy of A Newborn: Langerhans Cell Histiocytosis
}

\section{Yenidoğanda Lenfadenopati: Langerhans Hücreli Histiositozis}

\author{
Ayşenur Bahadır' ${ }^{1}$, Erol Erduran ${ }^{1}$ \\ ${ }^{1}$ Karadeniz Teknik Üniversitesi, Pediatrik Hematoloji-Onkoloji Bilim Dalı, Trabzon, Türkiye
}

Dergiye Ulaşma Tarihi: 06/11/2015 Dergiye Kabul Tarihi: 23/12/2015 Doi: 10.5505/aot.2016.04909

ÖZET

Langerhans hücreli histiositozis (LHH) etyolojisi tam bilinmeyen, myeloid dentritik hücrelerin nadir bir bozukluğudur. Lokalize kemik ve cilt lezyonları yapabileceği gibi multi organ yetmezliğine neden olabilecek kadar yaygın tutulum da yapabilir. Yenidoğan döneminde LHH'li hastalar sıklıkla cilt bulgusu ile tanı almaktadır. Hastaların ilk başvuru da lenfadenopati ile başvurması sık görülmemektedir.

Boyunda kitle? lenadenopati(LAP)? ön tanıları ile 35 günlük erkek hasta hastanemize başvurdu. Hastanın şikâyetleri 10 günlükken başlamıştı ve almış olduğu tedavilere rağmen boyundaki şişlik geçmemişti. Boyun ultrasonografisinde lenfadenit?, lenfoma? olarak değerlendirildi. Hastanın LAP'den alınan biyopsi sonucu LHH olarak raporlandi.

Bu yaş grubunda deri bulgusu eşlik etmeden, ilk başvuru şikâyeti LAP olup LHH tanısı koyulan literatürdeki nadir vakalardandır. Yenidoğan dönemindeki LAP'lerin çok iyi değerlendirilmesi, klinik ve ultrason görüntüsü ile LHH'un enfeksiyon ve malignite ile karışabileceği akılda tutulmalıdır.

Anahtar kelimeler: Langerhans Hücreli Histiyositozis, lenfadenopati, yenidoğan.

\begin{abstract}
Langerhans cell histiocytosis ( $\mathrm{LCH})$ is a rare disorder of myeloid dendritic cells with an unknown etiology. It may cause localized bone and skin lesions also may be so widespread that the involvement can lead to multiple organ failure. In the neonatal period, patients with LCH is often diagnosed by skin lesions. In the first application of the patient, lymphadenopathy is not an expected finding.

A 35 day old male patient was admitted to our hospital with a presumptive diagnosis of mass in the neck? lymphadenopathy (LAP). His complaints had begun when he was 10 days old and despite the taken treatment, swelling in the neck was ongoing. It was evaluated as lymphadenitis? lymphoma? with cervical ultrasonography. $\mathrm{LCH}$ was reported as a result of the biopsy taken from LAP.

In this age group without accompanying cutaneous manifestations, the first complaint as LAP in patients diagnosed with LCH is rare in the literature. During the neonatal period, a good evaluation of the LAP must be done and it should be kept in mind that clinical and ultrasound images of LCH may interfere with infection and malignancy.
\end{abstract}

Key words: Langerhans Cell Histiocytosis, lymphadenopathy, newborn

\section{Giriș:}

Langerhans hücreli histiositozis (LHH) myeloid dentritik hücrelerin nadir bir bozukluğudur. Halen etyolojisi tam olarak aydınlatılamamıştır. Bununla beraber patogenezde immun sistem disregülasyonu, infeksiyon ajanlarının reaksiyonuna bağlı 
olduğu düşünülmektedir (1). LHH lokalize kemik lezyonları yapabileceği gibi multi organ yetmezliğine neden olabilecek kadar yaygın tutulum da yapabilir. Özelikle karaciğer, dalak, kemik iliği gibi riskli organ tutulumları olduğunda mortalitesi artmaktadır. LHH'li hastalar s1klıkla ekzama veya seboreik dermatit gibi cilt lezyonları ya da skalp tutulumu ile başvurmaktadır $(1,2,3)$.

Hastaların ilk başvuru da lenfadenopati (LAP) ile başvurması sık görülmemektedir (4). Özellikle yenidoğan döneminde LHH'li hastalar sıklıkla cilt bulgusu ile tanı almaktadır (3). Yenidoğan döneminde şikâyetleri başlayan, 35 günlük iken boyunda LAP ile kliniğimize başvuran hastaya LHH tanısı koyduk. Bu yaş grubunda deri bulgusu eşlik etmeden, ilk başvuru şikâyeti LAP olup LHH tanisı koyulan nadir vakalardan biri olması nedeni ile rapor ettik.

\section{Olgu:}

32 yaşındaki annenin birinci gebeliğinden 39 haftalık spinal sezeryan ile doğan 35 günlük erkek hasta boyunda şişlik şikâyeti ile hastanemiz pediatri acil polikliniğine başvurdu. Doğumdan sonra yaklaşık olarak 10.günde kulak önünden boyuna yayılan bir şişlik ortaya çıkmış. Dış merkezde ayrı zamanlarda iki kez antibiyotik tedavisi verilen hastanın şikâyetlerinin gerilememesi nedeni ile hastanemize gönderilmiş.

Lenfadenit?, lenfadenopati? ön tanılarıyla pediatri hematolojiye konsulte edilen hasta, tetkik edilmek üzere hemotoloji servisine yatırıldi. Hastanın yapılan değerlendirilmesinde $\mathrm{Hb}: 10.9 \mathrm{mg} / \mathrm{dL}$ Lökosit: $19.000 \mathrm{u} / \mathrm{L}$ sedimentasyon: 79 mmsaat, CRP:9.59 mg/dL LDH:278 U/L GGT: 292 U/L AFP: $249.31 \mathrm{ng} / \mathrm{mL}$. Fizik muayenesinde sağ submandibular bölgede büyüğü yaklaşı1k 3 x 4 $\mathrm{cm}$ büyüklügünde çok sayıda LAP mevcuttu. Karaciğer kot altında $3 \mathrm{~cm}$ palpable, diğer sistem muayeneleri doğald.
Boyun ultrasonografisinde (USG); sağ submandibular bölgeden retroaurikular alana kadar uzanan $23 \times 17 \mathrm{~mm}$ ve $32 \times 24 \mathrm{~mm}$ boyutunda izoekoik LAP pakesi izlendi. Tanımlanan LAP'ler miks kanlanma paterni göstermekte olup ekojen hilusları seçilememekte, radyolojik görünüm malign tutulum (lenfoma) veya atipik enfeksiyon tutulumunu düşündürmekte olarak raporland. Nazofareks magnetik rezonans (MR) da; sağ submandibular, jugulodigastrik, posterior servikal bölgeye uzanım gösteren çok sayıda büyüğü 20x15 mm boyutunda konglemarat oluşturan T1 ve T2 A'da izointens çok sayıda LAP'ler izlendi (Resim 1). Akciğer grafisinde timüs gölgesi izlendi. Batın USG'de; karaciğer $90 \mathrm{~mm}$ olup hasta yaşına oranla normalin üst sınırında, karaciğer parankim ekosu homojen olup kitle izlenmemişti.

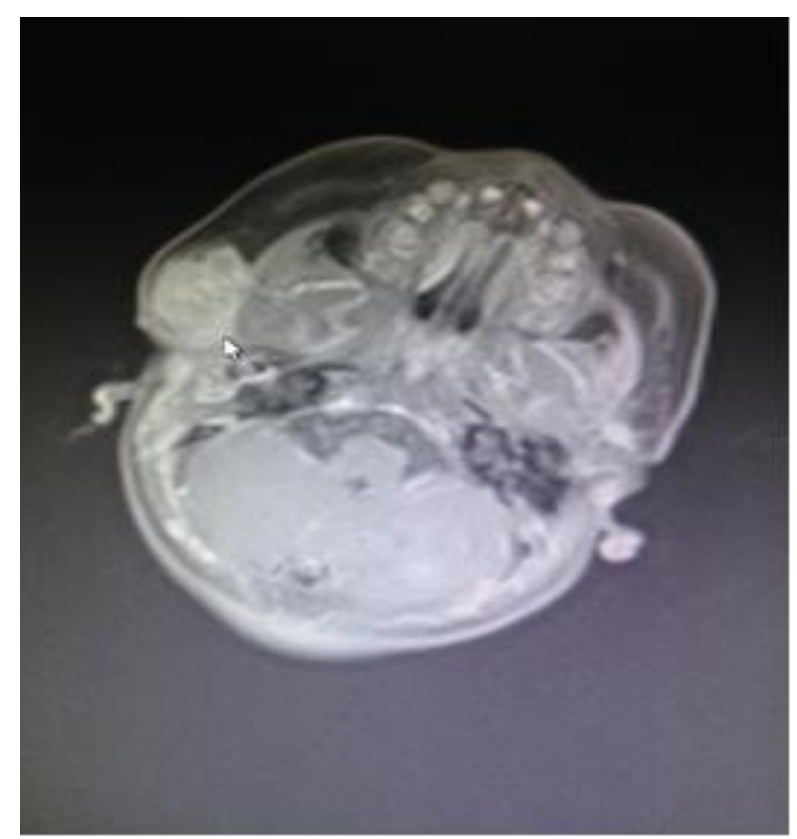

Resim 1: Nazofarenks MR'da T1'de săg submandibular üst juguler bölgeye uzanım gösteren çok sayıda lenfadenopati.

Hastanın kulak önündeki LAP'den, eksizyonel lenf nodu biyopsisi yapıldı. Biyopsi sonucu; $\mathrm{CD} 1 \mathrm{a}(+), \mathrm{S} 100$ protein zayıf $(+)$, LCA 
(-), pansitokeratin (-), PLAP (-), CD30 (-), CD $(-)$, CD20 (-), Langerhans hücreli histiyositoz olarak rapor edildi (Resim 2). Hastanın LHH açısından muhtemel tutulum yerleri olan kemik, akciğer, karaciğer taraması yapıldı. Toraks bilgisayarlı tomografisinde (BT) akciğer parankimi, içerisinde hareket artefaktı nedeniyle net değerlendirilemedi. Sağ akciğer üst lob posterior segmentte buzlu cam dansiteleri içerisinde langerhans hücreli histiostoz açısından şüpheli kistik görünümler izlendi. Abdominal BT; karaciğer vertikal uzunluğu $94 \mathrm{~mm}$ olup normalden büyük, kontürü düzgün, parankim dansitesi normal, dalak vertikal uzunluğu $77 \mathrm{~mm}$ olup normalden büyüktü. Kraniel MR normaldi. Kemik iliği aspirasyonu normaldi. Kemik sintigrafisinde tutulum izlenmedi.

Hastaya langerhans hücreli histiositozis tedavi protokolü (vinblastin $6 \mathrm{mg} / \mathrm{m}^{2}$ ve prednizolon $40 \mathrm{mg} / \mathrm{m}^{2}$ ) başland. Komple tam remisyonda olan hasta 2,5 yaşında olup kliniğimizde takip edilmeye devam edilmektedir.

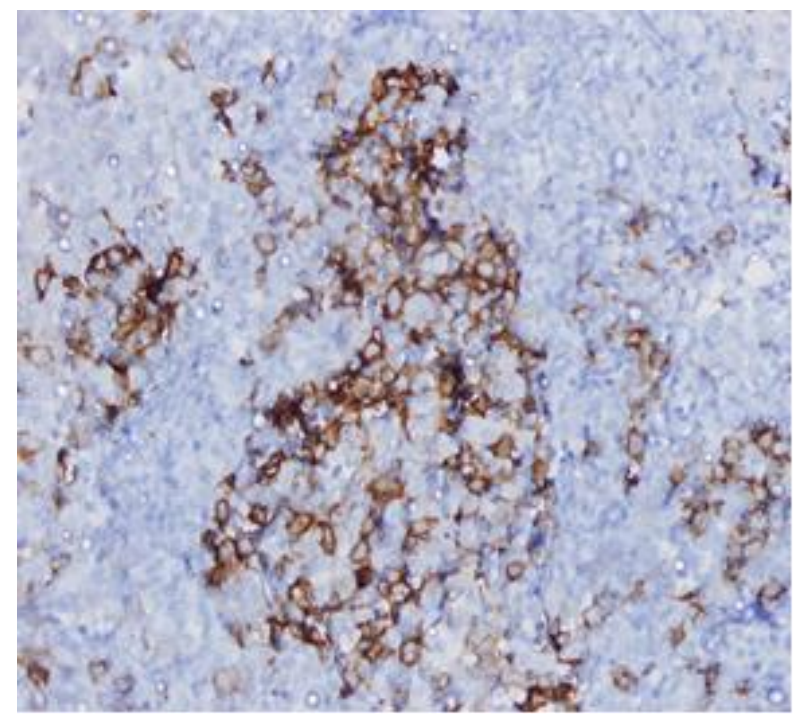

Resim 2: CD1a boyalı Langerhans hücreleri.

\section{Tartışma:}

Çocuklarda boyundaki kitleler genellikle gelişimsel, inflamatuar, neoplastik olmak üzere üç kısımda incelenir. Konjenital gelişimsel boyun kitleleri tiroglassal kist, brankial yarık kisti, dermoid kist, vasküler malformasyon ve hemanjiomlardir; İnflamatuvar boyun kitleleri reaktif LAP, infeksiyöz lenfadenit; benign neoplastik lezyonlar pilomatriksoma, lipom, fibrom, nörofibrom, tükrük bezi tümörleri; malign lezyonlar lenfoma, rabdomyosarkom, tiroid karsinomu ve metazlardır. Beş yaşından küçük çocuklarda en yaygın kitle nedeni LAP'lerdir. Kitle nedeninin aydınlatılmasında en önemli tetkiklerden biri USG'dir ve invaziv olmamas1 kolay yapılabilmesi en önemli avantajıdır. Ayrıca USG ile kitlenin solit, kistik ayırımı yapılabilmekte bize yol gösterici olmaktadır. Malignensi șüphesi olan durumlarda, kesin tanı için LAP'den biyopsi yapılması gerekmektedir (5).

Bizim hastamızın şikâyeti 10 günlük iken kulak önünde ve boyunda ele gelen şişlik şeklinde başlamıştı, dış merkezde lenfadenit olarak düşünülüp antibiyotik tedavisi almıştı ve tedaviye rağmen gerileme olmayınca tarafımıza başvurmuştu. Enfeksiyon açısından gönderilen EBV, CMV, toksoplazma sonuçları negatifti, ayrıca almış olduğu antibiyotik tedavisine rağmen LAP boyutunda küçülme olmamıștı. Hastamızın çekilen USG'de lenfoma şüphesi olması, tanısının netleştirilebilmesi için boyundaki LAP'den biyopsi yapıldı. Hastamızın LAP'den alınan biyopsi sonucu LHH olarak raporland. LHH açısından muhtemel tutulum yerleri olan kemik, karaciğer, akciğer, kemik iliği tarandı. Hastanın akciğer bulgusu olması, karaciğer tutulumu olması nedeni ile multisistemik LHH olarak kabul edildi ve sistemik kemoterapi başlandi. Kemik ve deri tutulumu yoktu.

LHH her y1l yaklaşı 2-10 milyon çocukta görülmektedir. Özellikle karaciğer, dalak, kemik iliği gibi riskli organ tutulumu 
olduğunda mortalitesi yüksektir. Hastalara verilen tedavi tekli organ tutulumu olmas1 ya da çoklu organ tutulumu olmasına bağlı olarak belirlenmektedir (2).

LHH da lenf nodu tutulumu sik görülmeyip, genellikle sistemik tutulumu olan olgularda görülmektedir. LHH'lu 15 gün-18 yaş arasındaki (ortalama 5 yaş) 133 hastanın ilk tutulum yerlerinin değerlendirildiği bir çalışmada; 114 hastada kemik, 34 hastada kulak, 30 hastada deri, 18 hastada karaciğer, 14 hastada akciğer, 14 hastada lenf nodu, 12 hastada dalak, 9 hastada diabetes insiputus, 2 hastada kemik iliği tutulumu saptanmıştır (4). Kwon ve arkadaşlarının (6) yapmış olduğu retrospektif çalışmada 30 vaka taranmış ve LAP ile başvuran vaka sayısı \%3.3 olarak bulunmuştur. Ayrıca bu çalışmada en sık başvuru şikâyetinin deri ve kemik tutulumu olduğu gözlenmiştir. Özellikle yenidoğan döneminde tanı alan LHH vakaları genellikle deri bulguları ile başvurmaktadır $(3,6)$. Bizim vakamızın deri bulgusu yoktu ve boyunda LAP

\section{Kaynaklar:}

1. Ribeiro KB, DDS, Degar B, Gianotti Antoneli CB, Rollins B, Rodriguez-Galindo C. Ethnicity, Race, and Socioeconomic Status Influence Incidence of Langerhans Cell Histiocytosis. Pediatr Blood Cancer, 2015; 62: 982-987.

2. Simko JS, Garmezy B, Abhyankar H, Lupo JP, Chakraborty R, Phaik Har Lim K, Shih A, Hicks J, Wright TS, Levy LM, McClain KL, Allen CE. Differentiating Skin-Limited and Multisystem Langerhans Cell Histiocytosis. J Pediatr 2014;165:990-6.

3. Tan Q, Gan Q, Wang H. Congenital self-healing Langerhans cell histiocytosis in a male neonate. 2015; 81 (1): 75-77. ile başvurmuştu. Bununla beraber hastanın tanıs1 netleştirildikten sonra yapılan taramasında akciğer ve karaciğer tutulumu da tespit edildi.

LHH özellikle infant döneminde en s1k başvuru şikâyeti cilt lezyonları olmakla beraber, nadir de olsa boyunda LAP ile başvurabilir. Yenidoğan dönemindeki LAP'ler yakın takip edilmeli, klinik ve USG görüntü olarak enfeksiyon ve malignite ile LHH'un karışabileceği akılda tutulmalıdır. Hastanın şikâyetleri gerilemediğinde en kısa sürede doku biyopsisi yapılıp hastalığın tanısının netleştirilmesi gerekir. Ayrıca LHH'da LAP tutulumuna sistemik organ tutulumunun da eşlik edebileceği unutulmamalı ve tedavinin planlanabilmesi için hasta ayrıntılı taranmalıdır.

Çıkar Çatışması: Yok
4. Braier J, Chantada G, Rosso D, Bernaldez P, Amaral D, Latella A, Balancini B, Masautis A, Goldberg J. Langerhans cell histiocytosis: retrospective evaluation of 123 patients at a single institution. Pediatr Hematol Oncol. 1999;16(5):377-385.

5. Meier JD, Grımmer JF. Evaluation and Management of Neck Masses in Children. Am Fam Physician. 2014;89(5):353- 358.

6. Kwon SH, Cho1 JW, Kim HJ, Youn SW. Langerhans cell histiocytosis: A retrospective analysis in a Korean tertiary hospital from 2003 to 2012. Journal of Dermatology 2013; 40: 824-828. 